\title{
An Investigation on Students Academic Performance for Junior Secondary Schools in Botswana
}

\author{
Luke Moloko Mphale $^{1}$, Mavis B. Mhlauli ${ }^{1 *}$ \\ ${ }^{l}$ Department of Primary Education, Faculty of Education, Private Bag 00702, \\ University of Botswana, Gaborone \\ *E-mail: mhlaulim@mopipi.ub.bw
}

\begin{abstract}
The major purpose of the study was to investigate factors which contribute to the decline in students' academic performance in junior secondary schools in Botswana since 2010. The study was mainly quantitative and used the positivist inquiry paradigm. The study employed critical theory for its theoretical framework. Questionnaires were used to gather data from two hundred participants. Some documents were analyzed to supplement the information collected through the questionnaire. Data were analysed using the computer package known as Statistical Package for the Social Sciences (SPSS) version 15. The findings of the study showed that there were several factors that can contribute toward students' low academic performance ranging from low staff morale to students unpreparedness for the examinations. The study, therefore, recommends that high teacher's morale, availability of resources and parental involvement are critical for the attainment of high quality education in Botswana secondary schools. Furthermore, the findings of the study have implications for research and practice.
\end{abstract}

Keywords: Academic performance, Botswana, quality education, parental involvement, instructional leadership, junior secondary schools.

\section{Introduction}

Education is regarded as a promoter of human development and seen by many to be in the centre of any society's life and concern. It is a social artifact embodying aspirations about the welfare and development of the society it deems to serve. To Batswana, education is expected to contribute towards the social, cultural, political and economic welfare and development of citizens (RNPE, 1994). According to Botswana educational goals, children who complete secondary education are expected to have acquired lifelong skills and be competitive in the global village when it comes to their employability (RNPE, 1994). This therefore, calls for students to excel academically or hopefully perform to the satisfaction of the nation.

In Botswana basic education is free to all children. The government is the sole sponsor for the education of the students from primary to secondary school levels. To some they receive government sponsorship at tertiary level. Since government committed itself to provide basic education for all, the Ministry of Education and Skill Development has been receiving a lion's share in both recurrent and development budget. Since 2007/2008 budget the Ministry of Education and Skill Development has been allocated over P5 billion of the recurrent budget. The 2013/2014 budget the Ministry of Education and Skill development is allocated P7.93 billion or 22.98 per cent of the ministerial recurrent budget 
(Matambo, 2013). Considering government hefty investment in education, its output with regard to the quality of students has not been commensurate with the expenditure. The students' academic performance has been declining at an alarming rate since 2010.Table 1 below shows yearly students' academic performance for 2010, 2011 and 2012, which indicate a serious decline. This has caused a concern for both the government and the public.

Table 1: Percentages of grades which are $\mathrm{C}$ or better in the Junior Certificate Examinations results for all candidates and in all syllabuses

\begin{tabular}{cc}
\hline Year & Percentage of grades C or better \\
\hline 2010 & $75.4 \%$ \\
2011 & $74.7 \%$ \\
2012 & $41 \%$ \\
\hline
\end{tabular}

Source: BEC 2010, 2011, 2012

In the past three decades there have been tremendous reforms in education systems worldwide (Kgosikebatho, 2013). As a result, concerns were raised by the public and educationists regarding the deteriorating standards of Botswana education system (Kgosikebatho, 2013). Recently in Botswana, teachers have been blamed for low students' performance and unjustified professional misconduct (The Botswana Gazette, 2013). This was the case because teachers' effectiveness may be determined by the grades the students obtain in their examinations. It is unheard of to dissociate teachers from their students' performance because they are responsible for interpreting and implementing policies. At least for the past three years since 2010, Botswana Junior Certificate Examination results have declined drastically and caused a lot of dissatisfaction among all stakeholders in education. The Ministry of Education and Skills Development (MoE\&SD) was requested to account for this disjuncture. This caused a serious rift between the MoE\&SD officials, teachers and teachers' unions. Some of the questions which might be asked include: What has caused this drastic decline of students performance? Is it justified to put the blame on teachers disregarding other stakeholders?

\section{Purpose of Study}

The major purpose of the study was to investigate the Botswana junior secondary school teachers' and students' views, ideas and experiences concerning factors which contribute towards students' low academic performance since 2010. It also explored strategies needed to alleviate the problem if any.

\section{Research Questions}

The following research questions guided the study:

1. How effective is the teaching and learning process in enhancing students' performance?

2. What factors contribute to low students' performance?

3. What strategies might be put in place to improve the students' performance?

\section{Theoretical Framework}

There is a growing concern nowadays about the type of students schools produce. The industry is now questioning the integrity of the present day teachers. The policy makers, educators and the parents have also joined the chorus. In this article, critical theory was used to understand the nature of problems attributed to the students' low performance. Critical theory is based on the fact that the respondents are human beings who need to be given freedom from the circumstances which seem to enslave them; and prescribe the type of behavior a democratic society is expected to entail (Basit, 2010). The approach is in agreement with the idea that; critical theory "provides the descriptive and normative bases for social 
inquiry aimed at decreasing domination and increasing freedom in all their forms" (Stanford Encyclopaedia, 2005, p.1). This seems to suggest that with critical theory the disempowered individuals are empowered. In this sense teachers have been criticised for the poor students' academic performance because they are duty bound to make students go through all forms of testing. They have been isolated from other education stakeholders and students' achievement is used to determine the teachers' effectiveness. Teachers have been threatened with job losses every time when the results are not pleasing the parents and the public. They are facing 'inequality' and 'discrimination' in spite of the fact that students' performance is determined by a number of factors which some teachers have no control over them. So, critical theory seeks to advance freedom and democracy for the betterment of individuals and society (Basit, 2010).

With these views we employed a critical lens to interrogate the teachers' and students views about the declining performance. With critical theory, "the researcher's aim is to explore perspective and shared meanings and to develop insights into situations e.g. schools, classrooms" (Wellington, 2000, p.16). Critical educators seek to learn what is meaningful or relevant to people by getting to know the social world and seeing it from the point of view of the people being studied (Neuman, 1997). Critical theory "identifies the 'false' or fragmented consciousness that brought an individual or social group to relative powerlessness or, indeed, power, and it questions the legality of this" (Cohen, Manion \& Morris, 2007, p.28). Critical theory was used in view of the fact that those who have an impact on students' achievement face challenges pertaining to the expectations of the Batswana and the purpose of schools.

\section{Literature Review}

Provision of quality education is a priority that every country will aspire to include amongst the national goals of education. Raising the standard of education is one of Botswana's national goals (Republic of Botswana, 1994). According Kimani, Kara \& Njagi (2013) the purpose of education is to equip the citizenry with values, skills and knowledge to reshape their society and eliminate inequality. This is because education helps an individual develop his/her capabilities, attitudes and behavior that is acceptable to the society. The benefits of having quality education is that it is able to adapt to the changing needs of the country as the world changes and spearhead the development of human resource and the country's economy.

Educational institutions are mandated to use education as a tool for social transformation. The success of a school is measured by the quality of students it produces. The success of any educational institution is measured by the performance of its students in both academic and non-academic tests. This is supported by Yusuf (2008) when contending that the performance should not only be based in terms of test and examination results and student ability to apply what is learnt and the rate at which students move on to higher institution of learning, but should include other areas such as whether the students have acquired the survival skills. In spite of that, the use of students' achievement in academic work to assess the teacher's effectiveness has gained ground. The measure of academic performance as a symbol of school success can be traced way back from the Victorian period (Bell, 2013). Since then, academic performance has been used to grade schools and most importantly to determine ones career paths. The 'good schools' are acclaimed to be those that are able groom the students well enough to achieve the set standards. This is measured by use of students' academic performance both at school level and nationally. The importance of students' high performance has attracted the attention of the public, policy-makers, educators, learners and ministry of education alike. DFE quoted in Gray \& Wilcox (1995, p.5) state that "better information about schools is also important for raising the standards. For example, publishing tables which compare the performance of schools has encouraged many schools to take a hard look at examination results their students achieve and how the school can help the pupils to do better." The level of students' performance has an impact on the roles played by education stakeholders. Students' achievement is influenced by a number of factors. For the purpose of 
this study factors such as school leadership, teacher's quality, parental support and students will be discussed in detail. Research has indicated that school leadership, teacher's quality, parental support and students are detrimental to students' high or low academic performance (MacNeil \&Maclin, 2005). Collaboration between school leaders, teachers, students and parents can assist in promoting students learning. Of recent, Botswana has established Parents, Children and Teachers Associations (P.T.S.A) as a sign of the stakeholders' commitment towards students achieving the school purpose.

\section{School Leadership}

The success of any school undoubtedly depends on the type of leadership that the school has. The current school leaders perform multiple functions as compared the past leaders. They perform managerial, instructional, curriculum, counsellor, arbitrator and in some cases advisory roles in the community. Researches have argued tirelessly on the link between quality leadership and school performance for many years. The conclusions reached made some authors to believe that no schools can be greater than their leaders and that a school is as good as its leadership (Yusuf, 2012; DfEE, 1999d). Emerson \& Goddard (1993) asserted that there is a strong link between the quality of a school and the quality of its leadership. While other authors contend that there is insufficient evidence to support the relationship between school leadership and students' academic performance (Witziers, Bosker \& Kruger, 2003). However, the majority of studies carried out about school leadership has revealed that school leadership quality directly impact the school success, teachers effectiveness and students' academic performance. The School Head is an overseer of all activities taking place in a school and answerable to activities within the school compound. His/her core business is the success of the school by making teaching and learning enjoyable and more effective. It is a wish for every School Head to be trusted, respected and praised by the community he serves. One of the factors that make school leaders to be belittled is when the school performs badly; and as such it is an area which the School Head will try to avoid at all cost. In order to sustain academic performance the leadership will have to create an academic achievement ethos, organize instruction throughout the school spectrum and aims to attain the target set by the supervisory department, thus becoming instructional leaders. There are several ways in which school leaders have an impact on the students' academic performance. One of the ways is the school leader being an instructional leader. Instructional leadership involves setting goals, managing curriculum, monitoring lesson plans, allocating resources and evaluating teachers regularly to promote student learning and growth (Concordia University, 2013). An effective instructional leadership is able to build the culture of learning, provide resources needed for quality teaching, and structure the classroom environment to stimulate teachers and learners motivation. Effective instructional leadership behaviour of the school leader has been shown to be the most crucial role to improve teachers' performance and students' academic achievement (Strauss, 2013). Using his supervisory role the head should have time to check what happens in the classroom. He should spare some of his time to observe teachers teaching. After lesson observation his duty should be that of advisory than castigation. He should give feedback on the teachers' strong and weak points. Always giving praise for the good work makes teachers valued and motivated to work an extra mile. Where proper advice is given, makes teachers happy and they will then work on their weakness to enhance their performance. In fact, teacher appraisal is part of the School Head duties.

Another way is school leaders being excellent communicators. They should constantly remind teachers, parents and students of the schools vision, mission, values; and the core purpose of the school as to provide teaching and learning. They should assure teachers and students that nothing is impossible even in times of hardships. They should listen to everyone in the school, be it students, ancillary staff or teachers. The school leaders should practice the shared leadership, where decision - making involve other education stakeholders. The ideas and opinions from the school community can help to improve students' academic performance. Their communicative skills can inspire trust, motivation and confidence among teachers and students. This can instil a sense of effectiveness in teachers and 
ultimately have a positive impact on students' academic performance. In their capacity as collaborative leaders the school leaders should encourage collaboration from teachers. Teachers should meet together as colleagues' to share knowledge, experiences and as well as sharing the risks they face with regard to the teaching and learning process. This eliminates teachers' isolation so that discussions about students' performance become a collective effort. Coupling with his collaborative leadership the school leader should be accessible, visible and approachable by members of school community. He should be seen to be always positive, be their role model and try to double individuals' effort to reinvent the process of teaching and learning and providing staff training and development. A successful instructional leader should possess excellent planning and observation skills as well as proficiency in research and evaluation of both teachers and students performance (Concordia,2013).

\section{Teachers}

Teachers for years have been regarded as the essential catalysts for school improvement and school improvement. They are the driving force and main resource in the development and academic growth of students as they are sources of knowledge and agents of change (Wallace, 2011). Teacher effectiveness has been the interest of policy makers, educators and parents. The effectiveness is measured by students' academic performance in both internal and external examination. It is a general feeling that students who fail the examinations are taught by ineffective teachers; on the other hand those who excel are taught by the very effective teachers. Research so far has shown that a teacher's effectiveness has an influence on the students' academic attainment (Afe, 2001). Logically it is so because teachers are the facilitators in the teaching and learning process. They interpret the subject matter and put theory into practice during their interaction with the students. The teacher is "increasingly becoming the focus of interest because of the key role that he or she plays in the delivery of quality education to the learner" (Taal, 1996, p.16). This seems to suggest that teachers are agents of change and as such are critical in the students' academic performance. Teachers are praised and rewarded for good performance. The government of Botswana introduced the rewarding system where teachers and students who excel in their external examination are given presents ranging certificates of appreciation to sponsored trips abroad. This year a School Head from Makhubu Junior Secondary School was sponsored to visit Britain for a month after the school having scored 98 per cent in the 2012 Junior Certificate Examination (J.C.E). It is the responsibility of teachers to impart knowledge, skill and encourage students' social development. This is enshrined in the employment contract and explicitly defined in their job descriptions. In addition to cultivating knowledge, skills and attitudes teachers are expected to help the students to identify and develop their potential. In the early stages of education teachers are charged with the responsibility to develop students' primary skills necessary for advancement. Teachers play a pivotal role in helping the students to direct their potential to achieve their destiny. Learners need to be prepared for these challenges that lie ahead of them. This is anchored in the idea that our world needs a generation of teachers who aim to "develop learners instead of teaching them, who help their pupils to become independent (learning to learn), who provide students with motivation and interest for life-long learning and urge them to become autonomous learners"(Bubblews, 2013, p.3).

Teachers use several techniques to assist students improve their academic achievement. They evaluate, assess and provide for students with special needs. Teachers are evaluators at classroom level for quality standard. They attend to students work during lessons, provide tutorials, mark students' homework and give feedback. If a disability is identified in a student, a teacher will work around the clock to assist the child to build confidence and recommend a remedy. This builds students competence and their academic performance improves. In addition teachers evaluate the curriculum, materials, education programs or initiatives that are in place for their suitability to students learning. 


\section{Parents}

Literature reviewed revealed that parental involvement in the activities of the school has a positive impact on students' academic achievement and the success of the school (Halsey, 2004; Christie, 2005). Parental involvement boosts the morale teachers because of the partnership that will have been established between the school and the community. The most crucial practice would be school leadership creating a climate that will attract parents to participate in their children's learning. Parents should not only be consulted when there is a fund raising activity, but also for activities which might not be taken as important. There are a number of things that parents can assist in their children's learning. Recently, Botswana has established Parents, Teachers and Students Associations (P.T.S.A) as a sign of the stakeholders' commitment towards students achieving the school purpose. The objectives of the association include promote positive behaviour amongst students, monitors students work and encourages cost-sharing of students tuition. Parents are capable of helping students do homework, tutoring, supervision of afternoon study periods, coaching sports and motivational talks. As long as they know that their contribution is recognized and is vital for the achievement of their children, parents will be more than willing to value their children's education. Parents raised children with the hope of making them better citizens. One of the parents' aspirations is to see the children having succeeded in their schooling. In developing countries where unemployment is rife parents care about their children academic performance because the status quo is, good results means better opportunities for more career choices and white collar jobs.

In a collaborative climate where there is a mutual relationship between parents and teachers, parents are accountable for their children's homework, provision of additional funds for students educational trips and school attendance. In Botswana government has endorsed parental involvement in the education and mandated schools to form Parent Teachers Associations (P.T.As). In this relationship parents have agreed to assist government in paying a small amount of money as P.T.A. levy and share the cost of students' tuition. The funds are used for school development and enhance students learning. Of recent, a new system of association has emerged in schools called Parent, Children and Teachers Association (P. C. T.A).The main objectives of the association are to promote positive behaviour amongst students and monitors students work. When parents see that their contribution is recognized their sense of belonging is enhanced. Once they own the school they share the blame for a decline in students' academic performance. In order to avoid such disappointment parent show interest in students' achievement by conducting daily spot checks on their work. This ultimately motivates students to be serious with their school work, hence improve their academic performance. Parents therefore have a major role in their children's education.

\section{Students}

The core business of schools is teaching and learning in order give students' quality education. As an affirmation on the above, it is stated that; "one of the indicators of quality education being provided is cognitive achievement of learners" (Kimani et al., 2013, p.2). It has been said previously that school leaders, teachers and parents have a critical role in providing quality education for students. But it can be argued that for quality education to prevail all education stakeholders should take part in the translation, interpretation and implementation of policies regarding achievement of high standards of education, including students. Much is said about how to help students achieve their academic performance and little is mentioned about how the students themselves have impact on their own achievements. It should be noted that whatever effort that teachers exert to enhance students learning, the honours lay with the students. ; Hence the proverb 'you can lead a horse to the river but you cannot force it to drink.' However, there is evidence from research which shows that students can play a critical role in improving academic performance (Nicholas \& Sutton, 2013; Tella, 2007). There are several ways in which students can have an impact on their academic achievement. Among others is 
students study habits. Study habits can be positive and negative. The negative aspect of students study habits will be dealt with later in the article. The positive study habit is when students attend to their school work, read book to search relevant information, schedule time for doing homework, attend tutorials and ask teachers questions where they do not understand the concepts taught. After tests have been marked students who work on teachers' feedback have high changes of improving their performance. Another is when the students work in groups when they are given an assignment or topics for discussion. The intelligent students will help the low achievers to upgrade their grades and enhance their confidence. In a mixed ability class it has been proven that if students are not streamed according to the students capability have a higher overall attainment and equitable outcomes (Boaler, 2008). The students involved in mixed-ability approach tend to have respect for each other. Students who value education as a means of obtaining survival skills normally take learning serious. They do extra work with the assistance of their teachers. This ultimately proves their academic performance. Negative study habit is when students have a negative attitude towards schooling, students' reluctance to learn and not preparing work before classes begin.

There are several factors which can contribute to students' poor academic performance. One of such is language barrier, which greatly affects students' academic performance in schools. Many students enter the classroom not fluent in the languages of instruction. These languages are used for testing students' mastery of subject content and used in the examinations. The student might understand the concepts in their mother but fails to express it in the language of examinations. At the end the student is rated a low achiever because of the language problem. According to Pinnock in Elsworth (2013) children take years to master their native language. Botswana is multi-national society with over twenty-five spoken languages. Before they have fully mastered their vernacular languages they are introduced to two languages which are Setswana and English. Setswana is regarded as a national language and English taken as an official language. Students are expected to learn Setswana until they finish secondary school while, English is a medium of instruction from primary up to university level. These languages are used for testing students' mastery of subject content and used in the examinations. The student might understand the concepts in their mother but fails to express it in the language of examinations. At the end the student is rated a low achiever because of the language problem.

Another factor is parenting styles. Parental involvement in the child's school improves his/her performance. But some of the ways in which parents groom their children can have a negative impact on students' academic performance. In real life there are parents who are authoritative in terms of school work is concerned. Parenting styles have been shown by researchers that they can have a negative impact on their children's performance. Permissive and uninvolved styles cannot assist in making children value their education. The permissive style is when the strictness over the children has been lifted. The children have the freedom of choice in their study. Children living under this style often neglect their studies in favour of immediate and entertaining achievements (Verial, 2013). All in fairness, it should be remembered that if you spare the rod you spoil the child. The uninvolved style has been revealed as the worst parenting style which contributes to low students' performance. Similarly the parents give their children control over their school work. They do not help children in their homework or even giving them emotional support when children have personal problems. This results in students' demotivation and lack of interest in schooling.

Poor study habits could be another contributing factor in poor students performance. Students' lack of study skills and commitment to achievement has a negative impact on academic performance. Negative attitudes towards schooling, students' reluctance to learn and preparation of work before classes begin make students not ready for tests and examinations. Other related factors such students' intelligence, socio-economic status and lack of resources are determinant of students' academic achievements. The deficiency in the above means low students academic performance.

Gottman cited in Verial (2013) believes in the authoritative style as it does less harm to the child's self-esteem and ability to think autonomously as opposed to uninvolved style where parents give 
their children control over their school work. They do not help children in their homework or even giving them emotional support when children have personal problems. This results in students' demotivation and lack of interest in schooling.

Home background and socio-economic status of the students have also been attributed to students' academic performance. Yinusa \& Basil (2008) suggest that the students' home background influence academic and educational success, while socio-economic status reinforces the activities and functioning of the teachers and students.

Lack of academic motivation has also been attributed to students' low achievement. Ramsdal, Gioerum \& Wynn (2013) attest that lack of academic motivation seems to be a prominent problem for numerous high school students. Further researches have indicated that an individual student's intelligence has the most significant impact on their ability to perform well academically (O'cala, 2010; Radzka, 2010; Boaler, 2008). Without mental capacity to understand and retain the imparted knowledge and skills they will not enjoy the teaching and learning. It has also been observed that intelligent students normally help the low achievers to upgrade their grades and enhance their confidence (Boaler, 2008). Other related factors include resources, behavioural problems, friend's factors, drugs or alcohol abuse, diet and physical activities (O'cala, 2010; Radzka, 2010; Boaler, 2008). The above factors are determinant of the students' academic achievement.

The ministry of education as the accounting agent for the policy makers was chastised by the opposition parties and parents to explain for yearly drop in students' academic performance. This trickled down to schools to provide answers, unfortunately information given to the public was not convincing. The rift between the ministry and the teachers unions widen as each party pointed at each for the poor results. The ministry blamed teachers for their efficiency and incompetence; while the teachers unions blamed the ministry for teachers' low morale due to unbalanced teacher-student ration, lack of consultations, hasty introduction of new junior certificate syllabi, inadequate resources and unfavourable level of operation for teachers (Hlabano, 2013). There were calls for the minister of education to resign for her poor performance as the top accounting officer in the ministry. Having observed serious deteriorating students' achievement made the researcher to be interested in finding out the cause of these poor quality students.

\section{Research Methodology}

The study used quantitative (positivist) approach and employed the natural-science inquiry paradigm. The paradigm portrays that there is a reality out there which is tangible, stable and apprehensible; and can be investigated independent of the researcher by observing, experimenting on a large number of participants resulting in the finding that can be analysed statistically and pruned for the purpose of generalization (Cohen, Manion \& Morris 2007). This ideology corroborates the idea that human beings inhabit a relatively stable, uniform, and coherent world that can be measured, understood and generalized (Gay \& Airasian, 2000). This suggests that in order to understand the reasons for the declining students' academic performance, the existing information can be sourced not only basing on the feelings and opinions of the researched; but as well as using other methods such as observation, measurement and numeric data. It advocates for the researcher to be detached from the respondents and as such the researchers tried their level best to distance themselves to avoid any form of bias creeping in.

\section{Participants}

As regard the sample size, it was difficult to determine the actual number of the respondents. One of the authors observes that "the most perplexing question to both novice and experienced researchers is the question of sample size" (Anderson, 1997, p.199). On the other hand Cohen, Manion \& Morris (2007) assert that the sample size is determined by the intended research design. As a result, we followed 
Anderson (1997) philosophy which delineates clear recommendations and conclusions that a suitable sample size should be one with thirty and above respondents. Other reasons for this sample size were for purposes of generalisation and to increase validity.

The study was conducted among two hundred participants (200) made up of forty-four (44) teachers, seventeen (17) School Heads, seventeen (17) Deputy Heads, seventeen (17) Heads of Department, seventeen (17) Senior teachers grade I, twenty-two (22) senior teacher grade II and sixtysix (66) students from Central region, Gaborone, South central, North, West region and Kgalagadi region. Of the two hundred (200) participants, one hundred and twenty-two (122) were females and seventy-eight (78) males. The respondents' age ranged between sixteen (16) years and forty-five (45) and above years. Students were asked to write their exact age. With regard to teachers' qualification one hundred and fifty-one (151) possessed a Diploma in Secondary Education; fort-four (44) had a bachelor's degree and five (5) possessed a master's degree. In the study, stratified sampling was used to select manageable groups of respondents. This type of sampling requires each stratum to be represented in the research because other senior posts have a low incidence relative to teachers and students. From each school which took part the researcher had to identify relevant stratums and their actual representation in the population. Then random sampling was used to select participants from each stratum. The positivist paradigm prefers stratified sampling because it ensures sample representativeness, irrespective of the sample size. Therefore, the above respondents were chosen because they have an impact on students' academic achievement.

\section{Data Collection Techniques}

The study used critical friends and the researcher's experience to design the questionnaire. The researchers developed the questionnaire. The questions were piloted using students, teachers, the School Head, members of the Parent Teachers Association from the neighbouring junior secondary school and the Principal Education Officer. Piloting was tried out for purposes of improving the questions' ability to do the job for which they are intended. Some authors believe that all data-gathering instruments should be piloted to test how long it takes recipients to complete them, to check that all questions and instructions are clear and to enable researchers to remove any items which do not yield usable data (Bell, 1996; Cohen, Manion \& Morris, 2007). After the corrections were made the interview questions were ready to be used in the main research.

Data were collected using quantitative methods which included questionnaires. For the Kgalagadi region, due to its geographical position, the questionnaire was posted through the School Head after having telephoned him and explained the purpose of the study. With regard to other areas the researchers administered the questionnaires through the school heads' permission. That was done a week before the schools closed for first term. The questions were both open-ended and closed-ended (the likert scale type). The questionnaire was favoured because it tends to be more reliable than an interview as it has the ability to avoid face to face interaction, thus reducing bias (Cohen, Manion \& Morris, 2007) and less costly in terms of money and time.

\section{Data Analysis}

The study used a computer package form of data analysis normally used for quantitative research. The package is formerly known as the Statistical Package for Social Science Version 15, but now appears as a modified version known as Statistical Product and Service Solution (SPSS) or IBM SPSS v. 19. Before the information was fed into the computer, certain things were taken into consideration following Monyatsi (2001) ideas. Firstly, it was decided that errors that might have occurred during the research be noted and eliminated, secondly the completed questionnaires were counted to check if there were any missing. Thirdly, it was checked if all questions were answered. Fortunately all questions were answered. Lastly, it was checked if the respondents represented all cadres of the senior 
management. After having completed the above exercise the data were ready for SPSS. The likert scale analysis followed Oppenheim's (1996) methods of working with the frequencies and percentages of the levels of agreement and disagreement of the respondents. The data collected was represented in the form of frequency, tables and percentages. As for open - ended questions code frame was used to interpret the findings. Different views from respondents were closely examined. This approach made the data more meaningful and understood.

\section{Limitations of the Study}

The limitations are outlined in view of the fact that the approaches used are reliable and valid; but they also have their shortcomings which were beyond the researchers' control. Due to time and financial constraints it was not possible to cover all teachers in the field. The study was confined to $0.5 \%$ (200) of informants currently involved in students' academic performance out of a population of approximately forty thousand $(40000)$ junior secondary school teachers and students(BEC, 2010). Although the sample is relatively small, it is representative of the teachers and students in the 206 junior secondary schools because the respondents were sampled from six of the ten inspectoral regions which have different settings. This brings in the issue of generalisation which is vital in determining the validity and reliability of the research design.

Data collected were mainly the respondents' perceptions about the students' academic achievement as well as their interpretation of the questions asked in the questionnaire. Being at the mercy of the respondents' good will may produce findings that favoured them and affect the quality of data collected. It is the researchers' opinion that sometimes data collected based on people's opinion can be tainted by personal bias. This was taken into account during the data analysis. The other limitation was failure to investigate the school inspectors and Botswana Examination Council officers' views about the declining students' academic performance. This would act as a proof for or against allegations that the introduction of the new Junior Certificate syllabi; the inability of the examinations to address the syllabi objectives and the new grading system (Malepa) contributed to the low performance.

\section{The Results and Discussions}

The findings of the study indicate the positive impact of classroom teaching on the students' academic performance. While the introduction of the new junior certificate syllabus and the new grading system being among the main contributors of poor students' achievement. Students' academic performance management has been a necessary part of every school life. The schools have been called to account for the disturbing academic performance. It is important to note that, "in today's knowledge economy, performance management is a vital system as it contributes to the success of an organisation in attracting and retaining the right people, training and developing these individuals [students] to realise their own potential as well as the organisation's [school] potential, and constitutes a system of evaluating and rewarding individuals [teachers] within the organisation" (Ngcelwane, 2008, p.8). This suggests that for the success of a school, students should be well trained in preparation of the examinations; and to achieve this, teachers should be motivated. The findings are discussed according to the Research Questions (RQs) and categorised into effectiveness of teaching, factors contributing to students' low performance and Strategies.

\section{RQ 1: Effectiveness of Teaching}

Many participants in Botswana junior secondary schools viewed the teaching process being effective in the teaching and learning process. Data were collected from closed - ended questions $6-14$. The focus was on its ability to improve students' knowledge and skills in problem-solving techniques, prepares 
students for final examinations, enhance students' performance, instill students self- control, acquisition of better communication skills, builds a sense of commitment, create a disciplined student body, enhance students motivation and change students attitudes towards teaching and learning. In this section the respondents were to show the degree of their agreement with the statements given and descriptive analysis was done for each item. The responses are shown in table 2 below.

Table 2. Responses on effective classroom teaching

\begin{tabular}{|c|c|c|c|c|c|c|c|c|c|c|}
\hline \multicolumn{11}{|c|}{ Participants Responses } \\
\hline Statement & $\begin{array}{l}\text { IE } \\
(\mathrm{Fr})\end{array}$ & $\%$ & $\begin{array}{l}\text { LE } \\
(\mathbf{F r})\end{array}$ & $\%$ & $\begin{array}{l}\mathbf{E} \\
(\mathbf{F r})\end{array}$ & $\%$ & $\begin{array}{l}\mathrm{VE} \\
(\mathrm{Fr})\end{array}$ & $\%$ & $\mathbf{N}$ & $\%$ \\
\hline $\begin{array}{l}\text { 6.Improves students' knowledge and ski- } \\
\text { lls }\end{array}$ & 12 & 6 & 16 & 8 & 34 & $\begin{array}{l}1 \\
7\end{array}$ & 138 & 69 & 200 & 100 \\
\hline 7.Prepare students for final examinations & 12 & 6 & 32 & $\begin{array}{l}1 \\
6\end{array}$ & 116 & $\begin{array}{l}5 \\
8\end{array}$ & 40 & 20 & 200 & 100 \\
\hline 8.Enhances students' performance & 16 & 8 & 28 & $\begin{array}{l}1 \\
4\end{array}$ & 106 & $\begin{array}{l}5 \\
3\end{array}$ & 50 & 25 & 200 & 100 \\
\hline 9.Instills students self-control & 12 & 6 & 39 & $\begin{array}{l}1 \\
9\end{array}$ & 133 & $\begin{array}{l}6 \\
7\end{array}$ & 16 & 8 & 200 & 100 \\
\hline $\begin{array}{l}\text { 10. Helps students to acquire better com- } \\
\text { munication skills }\end{array}$ & 12 & 6 & 39 & $\begin{array}{l}1 \\
9\end{array}$ & 117 & $\begin{array}{l}5 \\
9\end{array}$ & 32 & 16 & 200 & 100 \\
\hline 11.Builds a sense of commitment & 12 & 6 & 50 & $\begin{array}{l}2 \\
5\end{array}$ & 116 & $\begin{array}{l}5 \\
8\end{array}$ & 22 & 11 & 200 & 100 \\
\hline $\begin{array}{l}\text { 12.Creates a well-disciplined students } \\
\text { body }\end{array}$ & 16 & 8 & 50 & $\begin{array}{l}2 \\
5\end{array}$ & 106 & $\begin{array}{l}5 \\
3\end{array}$ & 28 & 14 & 200 & 100 \\
\hline 13.Enhancesstudents motivation & 16 & 8 & 28 & $\begin{array}{l}1 \\
4\end{array}$ & 100 & $\begin{array}{l}5 \\
0\end{array}$ & 56 & 28 & 200 & 100 \\
\hline $\begin{array}{l}\text { 14.Changes students attitudes towards } \\
\text { teaching and learning }\end{array}$ & 12 & 6 & 66 & $\begin{array}{l}3 \\
3\end{array}$ & 94 & $\begin{array}{l}4 \\
7\end{array}$ & 28 & 14 & 200 & 100 \\
\hline
\end{tabular}

Key: $\%=$ per cent; $N=$ number of respondents; $F r=$ frequency; $I E=$ ineffective; $L E=$ less effective; $E=$ effective; $\mathrm{VE}=$ very effective

As illustrated in table 2, one hundred and seventy-two (86\%) participants believed that classroom teaching improves students' knowledge and skills in problem - solving techniques. One hundred and fifty-six (78\%) felt that teaching prepares students for final examinations; it enhances students' performance, it builds a sense of students' commitment towards learning and enhances students' motivation. One hundred and forty-nine $(75 \%)$ were in agreement that classroom teaching instills self-control in students and helps students to acquire better communication skills. One hundred and thirty-four (67\%) were adamant that teaching assists in creating a well- disciplined students body, while one hundred and twenty-two (61\%) were positive in classroom teaching ability to change students' attitudes towards teaching and learning.

From the research findings above, it is certain that many participants perceive the teaching process as being effective in the preparation of students for high education standards. The effectiveness of teaching has been mentioned as detrimental to the success of the whole school in terms both academic and extra-curriculum activities (Akiri \& Ugborugbo, 2009; Yusuf, 2008). It can be argued that effective teaching can promote students development, motivation, commitment to school work and growth. With the culture of learning developed in schools, students are most likely to perform better. 


\section{RQ 2: Factors Contributing to Students' Low Performance.}

All participants complained about the inhibiting factors that render the effectiveness of teaching and learning process. The contributing factors mentioned are inadequate resources low teachers' morale, teachers strikes, lack of parental involvement, the new grading system, lack of teachers and students preparedness for change, lack of teachers' incentives, students not serious with their school work, poor leadership, the examination not addressing syllabi objectives and lack of support for homework. To investigate the participants' views data were collected from questions $15-25$ and open-ended question 28. The respondents were also asked to show their degree of agreement with the statements given and descriptive analysis is also done for each item. The responses are shown in table 3 below.

Table 3. Responses on factors which contribute towards students' low performance

\begin{tabular}{|c|c|c|c|c|c|c|c|c|c|c|}
\hline \multicolumn{11}{|c|}{ Participants Responses } \\
\hline Statement & S/D & $\%$ & D & $\%$ & $\mathbf{A}$ & $\%$ & S/A & $\%$ & $\mathbf{N}$ & $\%$ \\
\hline 15. Inadequate resources & 0 & 0 & 0 & 0 & 28 & 14 & 172 & 86 & 200 & 100 \\
\hline 16. Low teachers morale & 0 & 0 & 0 & 0 & 61 & 31 & 139 & 69 & 200 & 100 \\
\hline 17. Teachers' strikes & 0 & 0 & 0 & 0 & 28 & 14 & 172 & 86 & 200 & 100 \\
\hline 18. Lack of parental involvement & 12 & 6 & 16 & 8 & 66 & 33 & 106 & 53 & 200 & 100 \\
\hline 19. The new grading system & 0 & 0 & 28 & 14 & 106 & 53 & 66 & 33 & 200 & 100 \\
\hline $\begin{array}{l}\text { 20. Teachers and students preparedness for } \\
\text { change }\end{array}$ & 0 & 0 & 0 & 0 & 12 & 6 & 188 & 94 & 200 & 100 \\
\hline 21. Lack of teachers incentives. & 0 & 0 & 0 & 0 & 56 & 28 & 144 & 72 & 200 & 100 \\
\hline 22. Students not serious with their work. & 0 & 0 & 0 & 0 & 34 & 17 & 166 & 83 & 200 & 100 \\
\hline 23. Poor school leadership & 0 & 0 & 0 & 0 & 34 & 17 & 166 & 83 & 200 & 100 \\
\hline $\begin{array}{l}\text { 24. Examination not addressing syllabi ob- } \\
\text { jectives }\end{array}$ & 0 & 0 & 0 & 0 & 28 & 14 & 172 & 86 & 200 & 100 \\
\hline 25. Lack of support for homework & 0 & 0 & 0 & 0 & 61 & 31 & 139 & 69 & 200 & 100 \\
\hline
\end{tabular}

Key: $\%=$ per cent; $N=$ number of respondents; $F r=$ frequency; $S / D=$ strongly disagree; $D=$ disagree; $\mathrm{A}=$ agree; $\mathrm{S} / \mathrm{A}=$ strongly agree.

Table 3 shows the respondents views about factors that contribute to students low performance. All two hundred (100\%) respondents believed that inadequate resources, teachers' low morale, teachers' strikes, teachers and students unpreparedness for change, lack of teachers incentives, students not serious with the school work, poor leadership, the examinations not addressing the syllabi objectives and lack of support for students homework have an impact on students' academic achievement. One hundred and seventy-two (86\%) respondents felt that not involving parents in school activity and the new grading system (Malepa) can adversely affect students' performance.

For an open-ended question the responses were categorized into the followings themes: lack of teachers' incentives, poor working conditions, lack of parental involvement, teachers' laxity and students' lack of commitment to their work. Majority, one hundred and eighty-eight (94\%) of the respondents mentioned lack of teachers incentives, poor working conditions and lack of parental involvement in school activities as factors which contribute to poor students' academic performance. Six (3\%) mentioned teachers' laxity, while the other six (3\%) felt students' lack of commitment to their work being a contributing factor to their poor performance. For instance, a teacher had to say:

For teachers to be effective in the classroom they should be rewarded for the work well done and their working conditions be improved. 
Sharing the same sentiment a School Head asserted that:

The ministry of Education and Skill Development should think twice about teachers' conditions of service if it will continue calling teachers to account.

It is clear that teachers are unhappy about their conditions of service and lack of incentives.

Although the link between teachers' incentives and students achievement is highly debated in both public and education forums, there are evidences from research which indicates that students' performance improves when teachers are rewarded for good performance. In their research of school personnel practice Figlio \& Kenny (2000), found out that teachers salary incentives are associated with high levels of students performance (Gorman, 2013). It has been mentioned earlier in this article that parental involvement can boost students' achievement. Research has revealed that parents are willing to partake in school activities but they need direction from the school leaders on how to help (Epstein \& Jansorn, 2000).

The findings in this study have revealed the respondents ${ }^{6}$ dissatisfaction in executing their duties which contribute to poor students' performance. A large number of the respondents stated that the Botswana secondary schools face several contributing factors in poor students' performance. The majority mentioned lack of resources (mainly textbooks), low teacher morale, poor working conditions, teachers strikes, the new grading system, lack of parental involvement, lack of students' commitment to their study, incompetent School leadership and the new syllabi which is not thoroughly explained to teachers and claimed that it was introduced at a wrong time. Evidence from the literature review suggests that availability of resources; teachers' job satisfaction, motivation and teachers' morale are the key components of school success and students achievement (Bishay, 1996; Tella, 2007; Baker, 2011; WikiEducator, 2013).

\section{RQ3: Strategies to Alleviate the Declining Students' Performance}

Participants suggested a number of strategies to combat the deteriorating Botswana junior secondary school students' academic performance. To investigate the participants' views they asked to list strategies to alleviate deteriorating students' academic performance. The responses were categorized into the followings themes: team teaching, tutoring and students homework.

\section{Team Teaching}

Majority, one hundred and sixty-six (83\%) of the respondents suggested team teaching as the main strategy which can be used to alleviate the problem of deteriorating students' academic performance. Team teaching can have an impact on the quality of teachers and students academic performance. As teachers work as a team they prepare lesson plans together, teach the same classes together, mark students work together and prepare mock and final examination together. In this approach teachers are able to identify their problem areas, share insights and encourage one another to exert more effort in the teaching process. The weaknesses are attended by team members in a nonthreatening and supporting environment. Ineffective teachers will feel comfortable if they are critiqued by colleagues than if is done by the school administration, hence will be more than willing to improve their performance. For the quality of teaching and learning process team teaching should be encouraged. This was pointed out by one of the school head in the study when he had to say:

Team teaching improves students' achievement as teachers approach same topic from different perspectives, as more teachers explain the topic it is easily understood by students. 
The new appointees can be paired with the experienced teachers in order to build their confidence and competency in the subject content. On the part of the students seeing a different person with different personalities and values can stimulates motivation and interest in the lesson that is taught by the team. As the students' motivation increases, their academic achievement also improves. Buckley (2013) asserts that in team teaching students and teachers interact more by debating, disagreeing with conclusions, raise new questions and point out consequences. With this approach, students' achievement can be enhanced.

\section{Tutoring}

A small number of participants, twenty-two (11\%) mentioned tutoring as another strategy to be used to improve students achievement. Although few mentioned tutoring in the low profile among the contributing factor towards positive students' achievement, it is widely known to improve students' achievement. Whether is done privately or part of the teachers duties tutoring can have effect on both the slow learners and high achievers. For the low achievers it can upgrade them to keep up with other students and to the high achievers can help them to be more inquisitive. One other advantage of tutoring is that it can be done by students. Students act as tutors to other students as is sometime practiced in mixed-ability classes. The intelligent students help the low achievers to understand the material needed to pass tests and examinations. The ability of parents to tutor their children has been revealed by research (Epstein, 2004). Some parents are retired teachers, education officers and the like who are experts in a number of subject content. With such wisdom they can take their children through the examinations. This was echoed by a student saying:

Teachers and parents should provide tutoring after school hours.

The same sentiment was shared by a Deputy school who strongly believed that:

Parents should hire private tutor to supplement what schools provide to sustain quality standards.

Private tutoring has shown to have a positive impact on students' academic achievement (Lee, 2013).

\section{Students' Homework}

Giving students more homework is also poorly rated by the participants. Two (6\%) felt that giving students more homework can improve students' performance. This poor rating might be attributed to the negativity and reluctance of the parents to assist their children with homework given the fact that they also come back from work tired hence finding it difficult to pay attention to their children's school work. However, the significance of giving students some work to do at home cannot be overemphasized. Homework provides students with ability to learn at their own pace and to finish the work they were supposed to have finished during normal lessons. This also gives them the opportunity to work out of the classroom environment; where frustrations of not finishing classroom assignments do not exist. The use of homework is another way of giving parents responsibility to their children's academic achievement. Parents expect or wish to see their children succeeding in their final examinations and proceed to a high education level. So keeping parents involved in their children's academic performance reinforces skills taught in class. One wonders why the many teachers were not in favour of giving homework as a supplement to what they expect to teach. In present day teaching where teachers complain of congested syllabus; teachers can use homework to cover topics that will not be easy to cover before the examinations period.

Studies on the effect of homework on students show mixed feelings. Some indicate a link between homework and students achievement (Fernandes, 2011), while other research shows no links 
(Baker \& Lentedre, 2005). The problem is giving students too much homework or difficult homework that takes a lot of time to complete. This gives a negative impression about the value of homework. Research has revealed that homework has a positive impact on secondary school students' achievement than those in elementary school, but too much homework can be counter-productive for students of any grade level (Edvantia, 2007; Fernandes, 2011). This was also pointed out by one of the students when she stated that:

\section{We learn better when teachers give us extra work to practice at home.}

There is no doubt that homework is critical to the learning process of a student. If properly managed and feedback is regularly given to students, homework can positively affect the academic performance of students.

\section{Conclusions and Recommendations}

From the research findings, it is clear that majority of the informants were dissatisfied with the education system. Majority respondents strongly feel that lack of resources, poor working conditions, use of the new grading system (Malepa), time and lack of incentives had to a greater extent contributed to teachers' low morale, hence, exerted less effort in their daily duties. The findings of the study show that lack of parents' involvement in the welfare of their children immensely contributes to students' low performance. Therefore there is a need for other stakeholders to participate in the education of their children for the rapid changes in the Botswana education system. Students' attitudes towards their learning have been highlighted. There is a proverb which says "you can lead a horse to the river but you can't force to drink." But with proper guidance students' mindset can be changed. Effective teaching and learning result into high quality teaching staff required for high quality education for the Batswana. The following recommendations are suggested for consideration:

- Provision of adequate resource for teaching and learning should be a requirement.

- Enough time should be given to the implementation of new innovations.

- Full parent participation in the welfare of their children should be seriously considered in schools (strengthening the SPTA).

- Teachers should be recognised and rewarded for the good work.

- The school leadership should play a leading role when it comes to students' performance (Remember: A school is as good as its HEAD).

\section{Implications for future Research and Practice}

The findings of the study have implications on research and practice as further research is needed basing on the following:

- An investigation on students' academic performance for junior secondary schools in Botswana involving a larger sample of over $80 \%$ of the teaching fraternity for the betterment of the generalizability of the findings.

- A further investigation involving Directors, Chief Education Officers. Botswana Examination Council, policy-makers, politician, parents and students whose input will confirm or refute the alleged serious deterioration of Botswana Junior Certificate Examination. The research to be carried out over a longer period of time for at least two years.

- A comparative study between Botswana Junior Certificate Examination results and any neighbouring country with the Southern African Development Community (SADC) because they share the same history of education development. 
Having considered the above, the study suggests that in order for students' performance to improve, there should be cooperation and understanding amongst all people who contribute to the development and growth of the child. This is a challenge for the practitioners to reflect on their own practices in order to remedy the situation.

\section{References}

Afe, J.O. (2001). Reflection on becoming a teacher and the challenges of teacher education:Inaugural lecture series 64. Benin City: University of Benin.

Akiri, A. A. \& Ugborugbo, N.M. (2009).Teachers' effectiveness and students' academic performance in public secondary schools in Delta States, Nigeria. Stud home comm sci, 3(2) 107 -113.

Anderson, G. (1997). Fundamentals of educational research. London: Falmer.

Baker, L. M. (2011). The relationships between leadership practice and teacher motivation, capacity, and work setting as related to change in literacy instruction. Retrieved 27March,

2013 from:http://udini.proquest.com/view/the-relationships-between- pqid:2550133691/

Baker, D. P. \& Lentedre, G. K. (2005). National differences, global similarities: world culture and the future of schooling. Stanford, CA: Stanford University Press.

Basit, T. N. (2010). Conducting research in educational contexts. London: Continuum

Bell, M. J. (2013). Define academic performance. Retrieved 17April, 2013 from:http://www.ehow.com/about_4740750_define-academic-performance.html.

Bishay, A. (1996). Teacher motivation and job satisfaction: A study employing the experience Sampling Method. Journal of Undergraduate Sciences, 3, 147-154.

Buckley, J. F. (2013). Team teaching - Advantages, disadvantages. Education Encyclopedia, State $\begin{array}{lllll}\text { University. } & \text { Retrieved } & 4 & \text { September, } & 2013 \text { from: }\end{array}$ http://education.stateuniversity.com/pages/2493/team-teaching.html\#ixzz2dtgGQcC9.

Christie, K. (2005). Changing the nature of parent involvement. Phi Delta Kappa, 86(9),

$645-$ 646.

Cohen, L. Manion, L. \& Morris, K. (2007). Research methods in education (6 $6^{\text {th }}$ ed). London: Routledge.

Department of Education and Employment., (2000). Professional development. London: DfEE.

Edvantia. (2007). What research says about the value of homework: Research review. Centre for PublicEducation. $\quad$ Retrieved 15 August, 2013 from: http://www.centreforpubliceducation.org/site/apps/nlnet/content3.aspx? $=1$ vIXIiNOJwE\&b=511 $3503 \& \mathrm{ct}=6857715 \&$ notoc $=1$ \#researchmeans.

Elsworth, S. (2013). Do Language barriers affect student performance in school? Retrieved 8 June, 2013 from: http://everydaylife.globalpost.com/language-barriers-affect-student- performanceschool-

Emerson, C. \& Goddard, I. (1993). Managing staff in school. Oxford: Heinemann Educational.

Epstein, J.L. \& Jansorn, N.R. (2004). School, family and community partnership link the plan. Education digest, 69(6), 19-23.

Fernandes, L. (2011). Home has a positive effect on students' achievement: Duke study. Retrieved 04 September, 2013 from: http://link.service disqus.com/api/click?format=go\&key=Cfdfcf52dffdOa70296/bad275

Gay, L.R. \& Airasian, P. (2000). Educational Research: Competencies for Analysis and Application. London: Pearson Education.

Gazette., (2013). Poor junior certificate examination results. Gaborone: The Botswana Gazette.

Gorman, L. (2007). Teacher incentives and students' performance. Retrieved 3 September, 2013 from: http://www.nber.org/digest/jun07/w12627.html.

Halsey, P.A. (2004). Nurturing parent involvement: two middle level teachers share their secrets. The clearing House, 77(4), 135-137. 
Kimani, G. N., Kara, A. M. \& Njagi, L. W. (2013). Teachers' factors influencing students' academic achievement in secondary schools in Nyandarua County, Kenya. International journal of education and research, 1(3), 1-14.

Lee, J.Y. (2013). Private tutoring and its impact on students' academic achievement, formal schooling, and educational inequality in Korea. Columbia University: Unpublished, $\mathrm{PhD}$ thesis.

MacNeil, A. \& McClanahan, A. (2005). Shared leadership. Retrieved 14May, 2013 from:http://conx.org/content/m12923/latest/

Matambo, O. K. (2013). 2013 Budget speech. Gaborone: Government Printers

Kgosikebatho, K. (2013). Experts pinpoint causes of poor results. Retrieved 19 August, 2013 from: www.thepatriotonsunday.co.bw/experts-pinpoint-causes-of-poor-results.

Monyatsi, P.P. (2001). An investigation of the effectiveness of the current teacher appraisal system as practised in Botswana secondary schools. UNISA: Unpublished, $\mathrm{PhD}$ thesis.

Neuman, W.L. (1997). Social research methods-qualitative and quantitative approaches. Needham Heights: Allyn \& Bacon.

Ngcelwane, M. J. (2008). A critical assessment of the implementation of performance management in the Nelson Mandela Bay Municipality. Rhodes Investec Business School: Unpublished, Master's thesis.

Nichols, B. \& Sutton, C. (2013). Improving academic performance through the enhancement of teacher/student relationships: The relationship teaching model. A journal of the international Christian community for teacher education, 1(2), 1-2.

O'cala, M. (2010). Factors that affect student achievement. Retrieved 17 September, 2013 from: $\mathrm{http} / /$ voices.yahoo.com/ factors-that-affect-student-achievement-738248.html?cat=4.

Oppenheim, A. N. (1992). Questionnaire design, interviewing and attitude measurement. London: Printer Publishers.

Radzka, K. (2010). Factors that affect student achievement. Retrieved 17 September, 2013 from: $\mathrm{http} /$ /www.educationspace360.com/index.php/factors-that-affect-student-achievement.

Republic of Botswana. (1994). Revised National Policy on Education (RNPE). Gaborone: Government Printer.

Stanford Encyclopedia of Philosophy (2005). Critical theory. Retrieved 15April, 2013 from:http://plato.stanford.edu/entries/critical-theory/

Strauss, V. (2013). School principals and the rhetoric of 'instructional leadership'. Retrieved 27 August 2013 from: http://www.washingtonpost.com/blogs/answer-sheet/wp/ 2013/04/18

Taal, A. H. S. (1996). Teacher education and training in Sub-Saharan Africa: Teacher education in Africa, past, present and future. Dakar: UNESCO.

Tella, A. (2007). The impact of motivation on student's academic achievement in mathematics among secondary school students in Nigeria. Eurasia journal of Mathematics, Science \& Technology Education, 3(2), 149-156.

Verial, D. (2013). Relationship between parenting styles and academic achievement. Retrieved 08 June, 2013 from: http://everydaylife.globalpost.com/relation-between-parenting-stylesacademic-achieve...

Wellington, J. (2000). Educational research: Contemporary issues and practical approaches.London: Continuum.

WikiEducator (2013). Teacher motivation. Retrieved 12 April 2013 from: http://wikieducator.org/teacher-motivation.

Yusuf, A. F. (2012). Influence of principals' leadership styles on students' academic achievement in secondary schools. Journal of Innovative Research in Management and Humanities, 3(1), 113 121. 